\title{
Sorbinil does not prevent hyperfiltration, elevated ultrafiltration pressure and albuminuria in streptozotocin-diabetic rats
}

\author{
A.Körner, G. Celsi, A.-C. Eklöf, T. Linné, B. Persson and A. Aperia \\ Department of Pediatrics, St. Göran's Children's Hospital, Stockholm, Sweden
}

\begin{abstract}
Summary. The effects of aldose reductase inhibition on kidney function were studied in rats with streptozotocin-induced diabetes mellitus. Diabetic rats were fed sorbinil ( 20 and $50 \mathrm{mg} / \mathrm{kg}$ ) by daily gastric gavage and were compared with untreated diabetic rats and normal rats. The rats were under daily supervision with regard to blood glucose control, insulin administration and body weight. The aim was to promote continuous body growth and to maintain the blood glucose concentration at around $22 \mathrm{mmol} / \mathrm{l}$ without large day-today fluctuations. The renal functional changes observed in this well-established diabetic model closely resembled those reported in human Type 1 (insulin-dependent) diabetes mel-
\end{abstract}

litus. Sorbinil treatment completely prevented renal cortical sorbitol accumulation, but did not abolish kidney enlargement or the increase in ultrafiltration pressure and glomerular filtration rate. Albumin excretion was increased to the same extent in the sorbinil-treated and in the untreated diabetic rats. We conclude that increased metabolism of glucose to sorbitol does not cause the hyperfiltration in rats with streptozotocin-induced diabetes.

Key words: Streptozotocin diabetic rat, aldose reductase inhibition, glomerular filtration rate, ultrafiltration pressure, albuminuria.
Glomerular hyperfiltration, intrarenal hypertension and kidney enlargement are typical findings in the early stage of human Type 1 (insulin-dependent) diabetes mellitus as well as in experimental diabetes [1-4]. It has been shown that in experimental diabetes, elevations in single nephron glomerular filtration rate (SNGFR) result from concomitant elevations in ultrafiltration pressure and glomerular plasma flow [5]. It has been suggested that these early glomerular haemodynamic abnormalities, and in particular the elevated ultrafiltration pressure, constitute the major pathogenetic factor in the progressive glomerular sclerosis that eventually develops in a substantial number of Type 1 diabetic patients [6].

The mechanisms behind intrarenal hypertension and glomerular hyperfiltration in diabetes have not been fully clarified. One hypothesis suggests that disturbances in the polyol pathway induced by the increased cellular uptake of glucose via an insulin-independent transport system will alter the regulation of renal haemodynamics [7]. Evidence has been presented which both supports and rejects this hypothesis. Variations in the severity of diabetes and variations in diabetic control may have contributed to the inconsistencies in the results [5].

Such inconsistencies in previous reports indicate the need for a study with a well-standardized experimental protocol. This need is emphasized by the fact that numerous clinical studies have recently been started to test the effects of aldose reductase inhibitors on the various complications of diabetes in humans. The present study performed on rats with streptozotocin-induced diabetes has attempted to meet the above-mentioned need. The protocols were rigorously standardized so that the rats would present with a well-established diabetic model showing no great day-to-day fluctuations in the metabolic control. The aims were to maintain the blood glucose concentration at around $22 \mathrm{mmol} / 1$, to prevent the development of ketonuria and to ensure that the rats gained weight throughout the study. Sorbinil, an inhibitor of aldose reductase, was administered both at a lower $(20 \mathrm{mg} / \mathrm{kg})$ and a higher $(50 \mathrm{mg} / \mathrm{kg})$ dose by gastric gavage. To assess the efficacy of the sorbinil treatment, the renal sorbitol content was measured.

\section{Materials and methods}

Age-matched Sprague-Dawley male rats (Alab, Sollentuna, Sweden), which were fed a standard diet containing $21 \%$ protein and given water ad libitum, were used in all the experiments. Rats were randomly allocated into three groups: Control rats, "Untreated" diabetic rats, and Sorbinil-treated diabetic rats. 


\section{Induction of diabetes}

At 50 days of age diabetes was induced by injecting $65-70 \mathrm{mg} / \mathrm{kg}$ streptozotocin (Zanosar, Upjohn Co., Kalamazoo, Mi., USA) dissolved in $0.9 \% \mathrm{NaCl}$ into the tail vein. From day 3, diabetic animals received a daily s.c. injection of 2-4 IU insulin (Ultratard Human Novo, Novo Industries, Copenhagen, Denmark). The blood glucose concentration was measured daily for the short-term and weekly for the long-term studies with a reflectance meter (Reflolux II, Boehringer-Mannheim GmbH, Mannheim, FRG). Streptozotocintreated rats with non-fasting blood glucose concentrations below $17 \mathrm{mmol} / \mathrm{l}$ at $48 \mathrm{~b}$ after the injection were excluded from the study.

\section{Sorbinil treatment}

Of the diabetic animals, $50 \%$ (or one-half) were given the aldose reductase inhibitor Sorbinil (Pfizer Research, Groton, Ct., USA) throughout the study period. Sorbinil was suspended by sonication in distilled water $(8-10 \mathrm{mg} / \mathrm{ml})$, solubilized by titrating to $\mathrm{pH} 9.5-9.6$, resuspended by back-titration to $\mathrm{pH} 8.0$ and diluted to a final concentration $(4-5 \mathrm{mg} / \mathrm{ml})$ with distilled water. The freshly prepared sorbinil was given by gastric gavage one or two times per day in a total dose of $20 \mathrm{mg} / \mathrm{kg}$ and $50 \mathrm{mg} / \mathrm{kg}$, respectively. Diabetic control animals received equal volumes of the vehicle alone.

Investigations were performed 3 weeks (short-term studies) and 3 months (long-term studies) after the induction of diabetes. On the day of the experimental studies, the animals were weighed, anaesthetized with Inactin, $80 \mathrm{mg} / \mathrm{kg}$ i.p. (Byk-Golden, Konstanz, FRG) and allocated to the different protocols. In order to obtain optimal experimental conditions, different rats were used for each protocol.

\section{Renal function}

After tracheostomy the right jugular vein and right carotid artery were cannulated with thin polyethylene tubes for infusions, blood pressure recordings and blood sampling. Glomerular filtration rate (GFR) was determined as the clearance of inulin. For this reason inulin (Inutest, Laevosan-Gesellschaft, Linz, Austria) was administered, continuously diluted (5\%), in Ringer solution. After a prime dose of $1 \%$ of the body weight the infusion was started at the rate of $1 \mathrm{ml} \cdot 100 \mathrm{~g}$ body weight ${ }^{-1} \cdot \mathrm{h}^{-1}$. The ureters were exposed through a midline incision and cannulated with polyethylene catheters that were advanced almost to the entrance of the renal pelvis. After $60 \mathrm{~min}$ equilibration time, urine was collected for two (45-60 min) periods. The mean arterial pressure was recorded using a Statham transducer and a Grass model 7B polygraph. The chemical analyses of inulin in blood and urine were performed by the standard laboratory methods [8].

\section{Micropuncture technique}

After anaesthesia, the rats were intubated, cannulated and infused, using the same procedure as for the GFR determinations, except that $8 \%$ Inutest was given. The rats were placed on a heated table. The left kidney was exposed by a flank incision and gently separated from the adrenal gland and the surrounding perirenal fat, and then was immobilized in a plastic holder and continuously bathed with mineral oil. Under stereomicroscopic observation, with the aid of a micromanipulator, exactly timed (20-40 s) samples of tubular fluid were collected from the surface proximal convolutions of four to five nephrons for the determination of flow rate and inulin concentrations, the latter being measured fluorometrically by the method of Vurek and Pegram [9].

\section{Stop-flow pressure measurements}

The hydrostatic pressures were measured with a servo-controlled counter pressure device (Model 900 micropressure system, WPIWP Instruments Inc., New Haven, Ct., USA), using a stop-flow tech- nique. A proximal convoluted tubule (PCT) was randomly punctured with a pipette filled with lissamine green which was connected to the pressure recorder; then the free-flow pressure was measured. A more distal portion of the same PCT was identified by the passage of a small drop of dye and was cannulated with a Sudan-stained oilfilled pipette. The tubular flow was blocked with a large drop of oil and the stop-flow pressure recorded. In each rat we determined freeflow and stop-flow pressures in five to six PCTs. The ultrafiltration pressure was calculated using the equation: $P_{U F}=S F P-P_{T}$, where SFP is the stop-flow pressure and $P_{T}$ is the free-flow pressure.

The urinary albumin excretion rate was determined by the radial immunodiffusion technique [10] from the albumin concentrations in the same urine samples collected for clearance measurements. Rabbit anti-rat albumin antibodies and rat albumin for a standard curve were obtained from Nordic Immunological Laboratories (Tilburg, The Netherlands). Urine samples (diluted 1:10-1:20) were added in $5 \mu$ quantities by micropipette to agarose plates containing anti-rat albumin antibodies. Measurement of precipitation lines was performed after $48 \mathrm{~h}$. All samples were run in duplicate.

\section{Determination of cortical sorbitol content}

Sorbitol content was measured with sorbitol dehydrogenase in cortical kidney homogenates [11]. The majority of cells $(>85 \%)$ in cortical homogenate are proximal tubular cells. Less than 1 erythrocyte/1000 kidney cells are found in renal cortical slices [12]. Thus, sorbitol content of renal cortical homogenate is representative for polyol pathway activity in renal cortical tissue. On the other hand Malone et al. [13] have suggested that erythrocyte sorbitol content may be a useful index of sorbitol levels in other less accessible tissues in which diabetic complications occur.

\section{Other methods of analysis}

Plasma glucose concentration was determined by the glucose dehydrogenase method (Gluc-DH Method, Merck, Darmstadt, FRG). Sodium and potassium in serum and urine were measured by flame photometry.

\section{Statistical analysis}

All values, except for urinary albumin excretion, are given as the (arithmetic) means \pm SEM. According to their log normal distribution, the values for urinary albumin excretion are given as the geometric means (tolerance factor) after logarithmic transformation. The statistical analysis was performed with the analysis of variance (ANOVA) and statistical significance was determined by Tukey's test. A $p$-value less than 0.05 was considered significant.

\section{Results}

The cortical sorbitol content, 3 weeks after induction of diabetes, was significantly higher in the sorbinil-untreated diabetic rats $(0.61 \pm 0.03)$ than in age-matched control rats $(0.42 \pm 0.05 \mathrm{nmol}$ sorbitol $/ \mathrm{mg}$ wet tissue weight $)$. Sorbinil treatment, even in the lower dose, completely prevented cortical sorbitol accumulation $(0.44 \pm 0.03 \mathrm{nmol}$ sorbi$\mathrm{tol} / \mathrm{mg}$ wet tissue weight). The difference between treated and untreated diabetic rats was significant $(p<0.05)$.

All diabetic rats were markedly hyperglycaemic. The blood glucose concentration was not significantly different in the sorbinil-treated and untreated diabetic animals after 3 weeks $(23.7 \pm 0.53$ vs $24.6 \pm 0.23 \mathrm{mmol} / \mathrm{l})$ and after 3 months $(25.7 \pm 0.38$ vs $24.8 \pm 0.45 \mathrm{mmol} / \mathrm{l})$. Body weight of diabetic rats both untreated $(280.6 \pm 4.9 \mathrm{~g})$ 


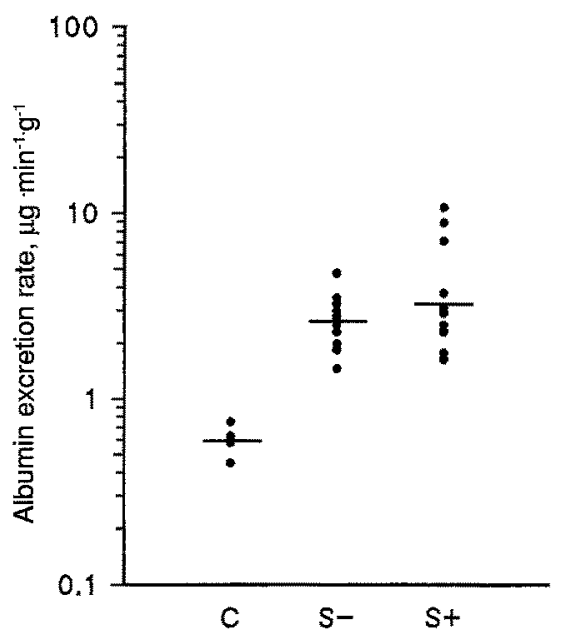

Fig. 1. Albumin excretion rate in control and diabetic rats 3 months after the induction of diabetes (long-term studies) $\mathrm{C}=$ control rats $(n=6), S-=$ sorbinil untreated diabetic rats $(n=12), S+=$ sorbinil-treated diabetic rats $(n=11), * p<0.05$

Table 1. Effect of diabetes and aldose reductase inhibition on kidney size and glomerular filtration rate (GFR)

\begin{tabular}{|c|c|c|c|}
\hline & $\begin{array}{l}\text { Kidney } \\
\text { weight/Body } \\
\text { weight }(\%)\end{array}$ & $\begin{array}{l}\text { GFR } \\
(\mathrm{ml} / \mathrm{min})\end{array}$ & $\begin{array}{l}\text { GFR } / 100 \mathrm{~g} \\
\text { body weight } \\
\left(\mathrm{ml} \cdot \mathrm{min}^{-1} \cdot \mathrm{g}^{-1}\right)\end{array}$ \\
\hline & \multicolumn{3}{|c|}{ Short-term ( 3 weeks) studies } \\
\hline Control & $\begin{array}{l}0.38 \pm 0.02 \\
(6)\end{array}$ & $\begin{array}{l}2.41 \pm 0.22 \\
(6)\end{array}$ & $\begin{array}{l}0.8 \pm 0.06 \\
(6)\end{array}$ \\
\hline $\begin{array}{l}\text { Diabetes } \\
\text { Untreated }\end{array}$ & $\begin{array}{l}0.50 \pm 0.02^{\mathrm{a}} \\
(8)\end{array}$ & $\begin{array}{l}3.69 \pm 0.1^{\mathrm{a}} \\
(8)\end{array}$ & $\begin{array}{l}1.32 \pm 0.07 \\
(8)\end{array}$ \\
\hline $\begin{array}{l}\text { Diabetes } \\
\text { Sorbinil } 20 \mathrm{mg} / \mathrm{kg}\end{array}$ & $\begin{array}{l}0.47 \pm 0.02^{a} \\
(8)\end{array}$ & $\begin{array}{l}3.89 \pm 0.22^{\mathrm{a}} \\
(8)\end{array}$ & $\begin{array}{l}1.32 \pm 0.09^{a} \\
(8)\end{array}$ \\
\hline \multirow[t]{2}{*}{$\begin{array}{l}\text { Diabetes } \\
\text { Sorbinil } 50 \mathrm{mg} / \mathrm{kg}\end{array}$} & $\begin{array}{l}0.49 \pm 0.02^{a} \\
(7)\end{array}$ & $\begin{array}{l}3.44 \pm 0.16^{\mathrm{a}} \\
(7)\end{array}$ & $\begin{array}{l}1.41 \pm 0.05^{\mathrm{a}} \\
(7)\end{array}$ \\
\hline & \multicolumn{3}{|c|}{ Long-term (3 months) studies } \\
\hline Control & $\begin{array}{l}0.32 \pm 0.02 \\
(6)\end{array}$ & $\begin{array}{l}1.43 \pm 0.12 \\
(6)\end{array}$ & $\begin{array}{l}0.29 \pm 0.03 \\
(6)\end{array}$ \\
\hline $\begin{array}{l}\text { Diabetes } \\
\text { Untreated }\end{array}$ & $\begin{array}{l}0.53 \pm 0.02^{\mathrm{a}} \\
(12)\end{array}$ & $\begin{array}{l}3.46 \pm 0.2^{\mathrm{a}} \\
(12)\end{array}$ & $\begin{array}{l}1.27 \pm 0.07^{\mathrm{a}} \\
(12)\end{array}$ \\
\hline $\begin{array}{l}\text { Diabetes } \\
\text { Sorbinil } 20 \mathrm{mg} / \mathrm{kg}\end{array}$ & $\begin{array}{l}0.52 \pm 0.02^{\mathrm{a}} \\
\text { (11) }\end{array}$ & $\begin{array}{l}4.04 \pm 0.22^{\mathrm{a}} \\
(11)\end{array}$ & $\begin{array}{l}1.33 \pm 0.05^{\mathrm{a}} \\
\text { (11) }\end{array}$ \\
\hline $\begin{array}{l}\text { Diabetes } \\
\text { Sorbinil } 50 \mathrm{mg} / \mathrm{kg}\end{array}$ & $\begin{array}{l}0.49 \pm 0.0^{\mathrm{a}} \\
(9)\end{array}$ & $\begin{array}{l}3.77 \pm 0.15^{\mathrm{a}} \\
(9)\end{array}$ & $\begin{array}{l}1.37 \pm 0.07^{\mathrm{a}} \\
(9)\end{array}$ \\
\hline
\end{tabular}

${ }^{a}$ Significantly different $(p<0.05)$ from control age-matched rats. Number of rats studied is given in parentheses

Table 2. Effect of diabetes and aldose reductase inhibition on single nephron glomerular function

\begin{tabular}{lll}
\hline & $\begin{array}{l}\text { Single nephron } \\
\text { glomerular filtration } \\
\text { rate }(\mathrm{ml} / \mathrm{min})\end{array}$ & $\begin{array}{l}\text { Ultrafiltration } \\
\text { pressure } \\
(\mathrm{mm} \mathrm{Hg})\end{array}$ \\
\hline Control & $30.04 \pm 3.9$ & $18.7 \pm 1.1$ \\
& $(10)$ & $(4)$ \\
Diabetes & $49.4 \pm 4.6^{\mathrm{a}}$ & $25.3 \pm 1.0^{\mathrm{a}}$ \\
Untreated & $(16)$ & $(4)$ \\
Diabetes & $48.7 \pm 4.4^{\mathrm{a}}$ & $25.1 \pm 1.4^{\mathrm{a}}$ \\
Sorbinil $20 \mathrm{mg} / \mathrm{kg}$ & $(19)$ & $(4)$ \\
\hline
\end{tabular}

${ }^{\text {a }}$ Significantly different $(p<0.05)$ from control age-matched rats. Number of rats studied is given in parentheses and treated with sorbinil $(286.8 \pm 5.6 \mathrm{~g})$ was significantly lower compared to control rats $(347.8 \pm 8.4 \mathrm{~g})$ already after 3 weeks. The diabetic rats grew throughout the study but the growth rate was slower than in the control rats. The ANOVA test showed a significant difference in body weight between control rats $(521.3 \pm 22.2 \mathrm{~g})$ and 3 -monthold diabetic rats $(273.3 \pm 7.4$ and $303.0 \pm 11.1 \mathrm{~g})$. There was no significant difference between the sorbinil-treated and untreated diabetic rats regardless of the administered dose.

The mean arterial pressure was not different in the three groups of rats at any time. After 3 weeks renal hypertrophy was apparent in both groups of diabetic rats. Both kidney weight and kidney weight/body weight ratio (Table 1) were significantly elevated. Increased kidney weight/body weight ratios were also observed after 3 months of diabetes (Table 1).

Both untreated and sorbinil-treated diabetic rats had a significantly higher GFR than the control rats, whether the GFR was expressed in absolute terms or was corrected for body weight (Table 1) and kidney weight. GFR/kidney weight $\left(\mathrm{ml} \cdot \mathrm{min}^{-1} \cdot \mathrm{g}^{-1}\right)$ in control rats at 3 weeks: $0.96 \pm 0.1$ and at 3 months: $0.84 \pm 0.12$. In untreated diabetic rats at 3 weeks: $1.34 \pm 0.07$ and at 3 months $1.2 \pm 0.08$. In diabetic rats treated with $20 \mathrm{mg} / \mathrm{kg}$ sorbinil at 3 weeks: $1.42 \pm 0.1$ and at 3 months: $1.29 \pm 0.07$. In diabetic rats receiving $50 \mathrm{mg} / \mathrm{kg}$ sorbinil at 3 weeks: $1.44 \pm 0.06$ and at 3 months $1.41 \pm 0.07$. Thus, sorbinil treatment in either dose failed to blunt the diabetic hyperfiltration. The GFR values in the different groups of diabetic rats were almost identical both at 3 weeks and at 3 months (Table 1).

The urinary albumin excretion rate was measured 3 months after the induction of diabetes and was significantly higher than in the control rats. The protein excretion rate was the same in the two diabetic groups (Fig.1).

Micropuncture studies were performed at 3 weeks. The results are shown in Table 2. The SNGFR was markedly elevated both in sorbinil-treated and untreated diabetic rats as compared to control rats. Ultra-filtration pressure $\left(\mathrm{P}_{\mathrm{UF}}\right)$ was also significantly higher in diabetic rats than in control rats. There was no significant difference between the treated and untreated diabetic rats with regard to $S N G F R$ and $\mathbf{P}_{\text {UF. }}$.

\section{Discussion}

Rats with streptozotocin-induced diabetes are frequently used as a model to study the mechanisms of renal functional changes and the mechanisms of nephropathy in human diabetes. If any clinical conclusions are to be drawn from experimental studies, the rats used in such a study should have a well-defined state of diabetes $[5,14]$. The rats in this study were under daily supervision with regard to blood glucose control, insulin administration and body weight. The renal functional changes observed in the streptozotocin-treated rats in this study closely resembled the changes observed in humans with insulin-dependent diabetes.

The possible role of alterations in the polyol metabolic pathway and the related abnormalities in the pathogen- 
esis of the secondary complications of diabetes have received increasing attention in the past several years [7]. Beyer-Mears et al. [15] reported in 1984 that 6 weeks after the induction of diabetes the glomerular sorbitol content had increased while the myo-inositol content had decreased and that these alterations were normalized by sorbinil treatment. These findings have led to the suggestion that glomerular hyperfiltration in diabetes may be linked to enhanced polyol pathway activity. Since then numerous experimental studies have been carried out to test this hypothesis. These experimental studies of activation of the polyol metabolic pathway and its role in the diabetes-associated renal alterations have so far not given any conclusive results [16-22]. Some of the inconsistencies in results might be attributed to differences in the severity of diabetes. In studies where an effect of aldose reductase inhibitors (ARI) on renal haemodynamics was noticed, typical renal effects of diabetes, e.g. kidney enlargement and/or hyperfiltration were generally absent or not very prominent indicating that the state of diabetes was very mild [16-18]. In addition, the causal relationship between increased polyol metabolism and the level of hyperperfusion was difficult to evaluate in these studies since data on renal tissue sorbitol content were not available.

A substantial number of well-controlled experimental studies do not support the hypothesis that increased metabolism of glucose via the polyol pathway causes the elevation in ultrafiltration pressure, GFR and albumin excretion. Chang et al. [19] reported that two different ARI (sorbinil and ponalrestat) did not significantly affect elevated GFR in diabetic rats. They did find that the ARI decreased the albumin excretion rate. Since the rats were studied only $2-4$ weeks after the induction of diabetes, it is unlikely that the albumin excretion rate reflected glomerular hypertension and/or glomerulosclerosis. It is more likely that the changes in albumin excretion rate reflected alterations in tubular reabsorption [20]. In a recent wellcontrolled study by Daniels and Hostetter [22] typical abnormalities of diabetes i.e. glomerular hyperfiltration, progression of albuminuria and glomerulosclerotic changes were not altered by treatment with the ARI ponalrestat.

In our well-established streptozotocin diabetic model we could document that the ARI sorbinil prevented the increase in renal cortical sorbitol content. Yet, sorbinil treatment had no effect on the hyperfiltration and also failed to prevent the late rise in albumin excretion. The results of our study corroborate and extend the work of Daniels and Hostetter in which ultrafiltration pressure and SNGFR were not measured. There are several lines of evidence suggesting that the increase in ultrafiltration pressure contributes to the initiation and progression of diabetic glomerulosclerosis [6]. Thus, our finding that sorbinil had no effect on these parameters, further supports the concept that ARI will not prevent the development of diabetic nephropathy.

Pedersen et al. [23] recently reported that administration of the ARI ponalrestat to diabetic patients for 6 months was accompanied by a reduction of the elevated GFR. They did not find any effect of the ARI on urinary albumin excretion. The patients that participated in this study did, however, have a very low albumin excretion, $5.4 \times / \div 1.9 \mu \mathrm{g} / \mathrm{min}$, suggesting that these patients were not at high risk for developing diabetic nephropathy. Since tissue sorbitol levels cannot be measured in clinical studies, it is impossible to conclude whether there are species differences with regard to the response of the diabetic kidney to ARI. It has been suggested that some ARI might influence renal function in diabetes by effects apparently independent of reduction in sorbitol levels [24]. It is, therefore, also possible that ARI might in these patients have had metabolic effects that indirectly lowered the GFR without causing a concomitant decrease in ultrafiltration pressure.

Acknowledgements. We thank Ms. M.Agrén, Ms. M.-L. Syrén and Ms. E. Zettergren for their assistance. This study was supported by the Swedish Medical Research Council (Project No.02049), the Swedish Diabetic Association and Swedish Hoechst Diabetes Fund.

\section{References}

1. Sandahl Christiansen JS, Gammelgaard J, Frandsen M, Parving H-H (1981) Increased kidney size, glomerular filtration rate and renal plasma flow in short-term insulin-dependent diabetics. Diabetologia 20: 451-456

2. Jensen PK, Sandahl Christiansen J, Steven K, Parving H-H (1981) Renal function in streptozotocin-diabetic rats, Diabetologia $21: 409-414$

3. Seyer-Hansen K (1983) Renal hypertrophy in experimental diabetes mellitus. Kidney Int 23: 643-646

4. Zatz R, Dunn R, Meyer TW, Anderson S, Rennke HG, Brenner BM (1986) Prevention of diabetic glomerulopathy by pharmacological amelioration of glomerular capillary hypertension. J Clin Invest 77: 1925-1930

5. Hostetter TH, Troy JL, Brenner BM (1981) Glomerular hemodynamics in experimental diabetes mellitus. Kidney Int 19:410415

6. Hostetter TH, Rennke HG, Brenner BM (1982) The case for intrarenal hypertension in the initiation and progression of diabetic and other glomerulopathies. Am J Med 72: 375-380

7. Greene DA, Lattimer SA, Sima AAF (1987) Sorbitol, phosphoinositides, and sodium-potassium-ATPase in the pathogenesis of diabetic complications. N Engl J Med 316:599-606

8. Hilger HH, Klümper JD, Ullich KJ (1958) Wasserrückresorption und Ionetransport durch die Sammelrohrzellen der Säugetierniere. Pflügers Arch 267: 218-226

9. Vurek GG, Pegram SE (1966) Fluorimetric method for the determination of nanogram quantities of inulin. Anal Biochem 16: $409-415$

10. Mancini G, Carbonara AO, Heremans JF (1965) Immunochemical quantitation of antigens by single radial immunodiffusion. Immunochemistry 2: 235-254

11. Finegold D, Lattimer SA, Nolle S, Bernstein M, Greene DA (1983) Polyol pathway activity and myoinositol metabolism. A suggested relationship in the pathogenesis of diabetic neuropathy. Diabetes 32: 988-992

12. Aperia A, Haldosen L-A, Larsson L, Gustafsson J-A (1985) Ontogeny of triamnicolone-acetonide binding sites in outer cortical tissue from rat kidneys. Am J Physiol 249: F891-F897

13. Malone JI, Leavengood $\mathrm{H}$, Peterson MJ, O'Brien MM, Page MG, Aldinger CE (1984) Red blood cell sorbitol as an indicator of polyol pathway activity. Diabetes $33: 45-49$

14. Bank N, Lahorra MAG, Aynedjian HS, Schlondorff D (1988) Vasoregulatory hormones and the hyperfiltration of diabetes. Am J Physiol 254: F202-F209

15. Beyer-Mears A, Ku L, Cohen MP (1984) Glomerular polyol accumulation in diabetes and its prevention by oral sorbinil. Diabetes 33: 604-607 
16. Bank N, Mower P, Aynedjian HS, Wilkes BM, Silverman S (1989) Sorbinil prevents glomerular hyperperfusion in diabetic rats. Am J Physiol 256: F1000-F1006

17. Tilton RG, Chang K, Pugliese $G$ et al. (1989) Prevention of hemodynamic and vascular albumin filtration changes in diabetic rats by aldose reductase inhibitors. Diabetes $37: 1258$ 1270

18. Goldfarb S, Simmons DA, Kern EFO (1986) Amelioration of glomerular hyperfiltration in acute experimental diabetes mellitus by dietary myo-inositol supplementation and aldose reductase inhibition. Trans Assoc Am Phys 99: 67-72

19. Chang WP, Dimitriadis E, Allen T, Dunlop ME, Cooper M, Larkins RG (1991) The effect of aldose reductase inbibitors on glomerular prostaglandin production and urinary albumin excretion in experimental diabetes mellitus. Diabetologia 34: 225-231

20. Cohen RA, MacGregor LC, Spokes KC, Silva P, Epstein FH (1990) Effect of Myo-Inositol on renal Na-K-ATPase in experimental diabetes. Metabolism 39: 1026-1032

21. Mauer SM, Steffes MW, Azar S, Brown DM (1989) Effects of sorbinil on glomerular structure and function in long-term diabetic rats. Diabetes 38: 839-846
22. Daniels BS, Hostetter TH (1989) Aldose reductase inhibition and glomerular abnormalities in diabetic rats. Diabetes 38: $981-$ 986

23. Pedersen MM, Christiansen JS, Mogensen CE (1991) Reduction of glomerular hyperfiltration in normoalbuminuric IDDM patients by 6 months of aldose reductase inhibition. Diabetes 40 : $527-531$

24. Craven P, DeRubertis FR (1989) Sorbinil suppresses glomerular prostaglandin production in the streptozotocin diabetic rat. Metabolism 38:649-654

Received: 10 July 1991

and in revised form: 23 December 1991

Prof. A. Aperia

Department of Pediatrics

St. Göran's Children's Hospital

Karolinska Institute

S-11281 Stockholm

Sweden 